\title{
Review on the Reproductive Health Problem of Dairy Cattle
}

\author{
Tagesu Abdisa* \\ School of veterinary medicine, Oromia, Ethiopia
}

Submission: November 22, 2017; Published: February 05, 2018

*Corresponding author: Tagesu Abdisa, Jimma university, School of veterinary medicine, Oromia, Ethiopia, Tel: +251933681407;

Email: adisatagesu@gmail.com

\begin{abstract}
Reproductive disorders have been found to be a major reason for decreased reproductive efficiency in cattle and consequently reproductive efficiency is the major determinant of lifetime productivity of cows. Among the major reproductive problems that have direct impact on reproductive performance of dairy cows are abortion, dystocia, retained fetal membrane (RFM), pyometra, metritis, prolapse (uterine and vaginal), anoestrus, repeat breeding and these results, in considerable economic loss to the dairy industry due to slower uterine involution, reduced reproductive rate, prolonged inter-conception and calving interval, negative effect on fertility, increased cost of medication, drop in milk production, reduced calf crop and early depreciation of potentially useful cows. It is very difficult to diagnose those problems by one particular disorder or symptom because there is interrelation between predisposing factors such as management at calving, hygiene and parity, stage of gestation, nutrition and environment. The objective of this paper is to review the main problem of reproductive disorder cow and its' causative factor.
\end{abstract}

Keywords: Abortion; Dairy cow; Dystocia; Reproductive disorder

\section{Introduction}

Reproductive disorders have been found to be a major reason for decreased reproductive efficiency in cattle and consequently reproductive efficiency is the major determinant of lifetime productivity of cows [1]. In the last few decades, as the major epidemic disease, were brought under control, emphasis have increasingly shifted to economically important diseases to the dairy producers and animal health problem stands out as the most prominent [2].

Regular breeding depends upon the normal function of the reproductive system. In order to breed regularly, the cow has to have functional ovaries, display estrous behavior, mate, conceive, sustain the embryo through gestation, calve, and resume estrous cyclist and restore uterine function after calving. Each of these aspects of reproductive function can be affected by management, disease and the genetic make-up of the animal. When the function of the reproductive system is impaired, cows fail to produce a calf regularly [3].

Among the major reproductive problems that have direct impact on reproductive performance of dairy cows are abortion, dystocia, retained fetal membrane (RFM), pyometra, metritis, prolapse (uterine and vaginal), anoestrus and repeat breeding. They are classified as before gestation (anoestrous and repeat breeding), during gestation (abortion, vagina prolapse and dystocia) and after gestation (retained fetal membrane and | uterine prolapse [4]. Upon closer examination of reproductive processes in the dairy cattle, the post-partum period is the most varied and vulnerable to problems and that incidentally coincides with the peak of milk production, uterine involution, and resumption of ovarian activity, conception and greater risk to infection [5].

These results, in considerable economic loss to the dairy industry due to slower uterine involution, reduced reproductive rate, prolonged inter-conception and calving interval, negative effect on fertility, increased cost of medication, drop in milk production, reduced calf crop and early depreciation of potentially useful cows [6].

It is very difficult to diagnose those problems by one particular disorder or symptom because there is interrelation between predisposing factors such as management at calving, hygiene and parity, stage of gestation, nutrition and environment [2]. Therefore the main objective of this review is to determine the risk factor and causative of reproductive problem in dairy animals.

\section{Reproductive Problem of Dairy Cow}

Reproduction is a complex processes where by individuals produce their off spring to perpetuate life [3].The sexual activity of the adult bovine female, non-pregnant, and in good health condition is cyclic and the cycle lasts for 20 to 21 days with 
extremes varying from 17 to 24 days; this for heifers and for cows [7].

The root cause of the declining health of dairy is a combination of a variety of psychological and management factors that have an additive effect on reproductive efficiency. The dairy industry depends on reproductive performance of their dairy cows in order to meet the growing demand products. The lactation cycle is dependent on the cow's ability to become pregnant since the hormones released during and after pregnancy are necessary for the development of the mammary gland and increase production of milk and milk products [8].

In the female a complex hormonal interaction exists which is responsible for the maintenance of the normal ovarian cycle, adaptation of the reproductive structures to maintain and hold the embryo and fetus during the gestation period and the development and functioning of the mammary glands [3]. As its complexity, sometimes the occurrence of anomalies (abnormalities) related with reproduction starting from the time of fertilization to parturition and possibly following that should not be earth- shaking news. This may occur in the absence of any readily apparent change in management [9].

According to [10] analysis, retention of fetal membranes (RFM) and the sub sequent endometritis and pyometra have been reported to be the most clinical and economical problems associated with reproduction that have a direct impact on reproductive performance of dairy cows. These have been implicated to cause a considerable economic loss to dairy industry due to slower uterine involution, reduced reproductive rate, and prolonged inter conception period and calving interval, high cost of medication, drop in milk production, reduced calf crop and early depreciation of potentially useful cows [11].

It has also been shown that low reproductive efficiency hinders genetic improvement in dairy cow and cause direct economic loss. Besides RFM, metrities and pyometra, abortion, repeated breeding, vaginal and uterine prolapsed, fetal mummification, prenatal and neonatal mortality and dystocia have also be reported as reproductive health problems in dairy cows [7]. Studies which have been conducted to assess major reproductive health disorders in cross breed dairy cows indicates that reproductive disorders such as clinical endometritis, abortion, RFM, dystocia and repeat breeding were one of the major reproductive disorders responsible for the low reproductive performance of dairy cows. The study also shows that periodical examination of cows during postpartum period was essential; since most cows acquire uterine infection during this period [12].

Among the problems postpartum anoestrus and repeat breeding were the major one, while prepartum problems such as metritis, abortion, retained placenta, dystocia and prolapse were found to be the leading reproductive problem. Qualitative study indicates, the difference in prevalence of the major reproductive problems on the basis of parity and body condition score [13]. As study showed that the repeat breeding, anoestrus, retained fetal membrane (RFM), and dystocia were found to be the major reproductive health problems with high prevalence and other reproductive health problems that include vaginal prolapse, abortion, mixed and uterine prolapse observed with low prevalence in the study farms of the area [14].

\section{Characteristics of the Major Reproductive Problems}

\section{Abortion}

Abortion is diagnosed and defined as the termination of pregnancy after organogenesis is completed but before the expelled fetus can survive. Abortion is the premature expulsion of the fetus from the dam and usually occurs because the fetus has died in utero. If death occurs at 1 or 2 months of gestation, it is usually termed "early embryonic death." When the fetus in near term and born dead it is often called "stillbirth". This stillbirth could have occurred due to difficult birth and the death of the fetus, or it may have died in utero due to disease and was expelled. The etiologic diagnosis of abortion in livestock is difficult and often frustrating task, and the diagnosis success rate is relatively low; $30-40 \%$ for bovine and numerous factors complicate diagnosis. Often, abortion follows initial infection by weeks or month so that the causative agent is no longer apparent by the time abortion occurs. In general term the cause of abortion are classified in to two groups; infectious and noninfectious [15].

Table 1: The bacterial infections which cause abortion in dairy cattle.

\begin{tabular}{|c|c|c|}
\hline Bacterial Infectious Agent & Time Of Abortion & Lesion \\
\hline Brucellaabortus & $\begin{array}{c}\text { P-9 months. Abortion } \\
\text { or stillbirth 2 week to 5 month after } \\
\text { infection }\end{array}$ & $\begin{array}{c}\text { cotyledons necroticred-yellow, } \\
\text { area between thickened. }\end{array}$ \\
\hline Brucellosis-Bang's disease & $5-8$ months & $\begin{array}{c}\text { Placenta: mild placentitis, } \\
\text { hemorrhagic cotyledons and } \\
\text { Campylobacter foetus }\end{array}$ \\
\hline Venerealis Vibriosis & & $\begin{array}{c}\text { Foetus: fresh or autolysed; mild fibrinous pleuritis, peritonitis, } \\
\text { bronchopneumonia. }\end{array}$ \\
\hline
\end{tabular}




\begin{tabular}{|c|c|c|}
\hline $\begin{array}{c}\text { Leptospirainterrogans, } \\
\text { serovarsgrippotyphosa, } \\
\text { pomona,hardjo, } \\
\text { canicola,icterohaemorrh agiae }\end{array}$ & $\begin{array}{c}\text { Last trimester } \\
\text { Abortion 2-5 weeks } \\
\text { after infection }\end{array}$ & $\begin{array}{c}\text { Placenta: diffuse placentitis with avascular, } \\
\text { light tan cotyledons and edematous, yellowish } \\
\text { intercotyledonary areas Foetus: autolysed }\end{array}$ \\
\hline $\begin{array}{c}\text { Arcanobacterium (Actinomyces) } \\
\text { pyogenes }\end{array}$ & Any stage & $\begin{array}{c}\text { Placenta: endometritis and diffuse placentitis, } \\
\text { reddish brown to brown colour. Foetus: autolysed, fibrinous } \\
\text { pericarditis, pleuritis, or peritonitis }\end{array}$ \\
\hline Listeria monocytogenes & $\begin{array}{c}\text { Dam: fever, inappetancePlacenta: retained. } \\
\text { Foetus: autolysedFibrinouspolyserositis }\end{array}$ & $\begin{array}{c}\text { Last trimester } \\
\text { and white necrotic foci in the liver and/or cotyledons. }\end{array}$ \\
\hline
\end{tabular}

Table 2: The viral infection which cause abortion.

\begin{tabular}{|c|c|c|}
\hline Viral Infectious & Time of Abortion & Lesion \\
\hline Bovine Viral Diarrhoea Virus (BVDMD) & Abortion usually up to 4 months & $\begin{array}{l}\text { Placenta: retained, no specific lesions. } \\
\text { Foetus: no specific lesions, autolysed, Mummified }\end{array}$ \\
\hline $\begin{array}{c}\text { Bovine Herpesvirus type I (BHV I) Infectious } \\
\text { Bovine rhinotracheitis virus }\end{array}$ & $\begin{array}{l}\text { Possibly any stage but most commonly } \\
\text { from } 4 \text { months to term }\end{array}$ & $\begin{array}{l}\text { Placenta: necrotizing vasculitis Foetus: autolysed, foci } \\
\text { of necrosis in the liver }\end{array}$ \\
\hline Blue tongue virus & Variable & Foetus: autolysed \\
\hline $\begin{array}{l}\text { Blue tongue } \\
\text { Aspergillussp (60- } \\
\text { 80\%Mucorsp,Absidia, } \\
\text { orRhizopussp }\end{array}$ & $\begin{array}{l}4 \text { months to term most common in } \\
\text { winter }\end{array}$ & $\begin{array}{c}\text { Cotyledons enlarged, necrotic, intercotyledonary area } \\
\text { is thickened and leathery. Foetus: autolysed } \sim 30 \% \\
\text { have gray ring worm like skin lesions principally } \\
\text { involving the head and shoulders. }\end{array}$ \\
\hline $\begin{array}{c}\text { Tritrichomonas (Trichomonas) foetus } \\
\text { Trichomoniasis }\end{array}$ & First half of gestation & $\begin{array}{c}\text { Placenta: retained, mild placentitis with hemorrhagic } \\
\text { Cotyledons and thickened intercotyledonary areas } \\
\text { covered with flocculent exudates. Foetus: no specific } \\
\text { lesions. }\end{array}$ \\
\hline Neosporacaninum Neosporosis & Any stage, but most often 5-6 months & $\begin{array}{c}\text { Placenta, foetus: no specific gross lesions, } \\
\text { autolysed. Microscopic: focal encephalitis with } \\
\text { necrosis and Nonsuppurative inflammation, hepatitis } \\
\text { in }\end{array}$ \\
\hline
\end{tabular}

The infectious cause includes; bovine viral diarrhea (BVD), infectious bovine rhinotracheitis (IBR, bovine herpes virus 1), letopirosis, brucellosis, mycotic abortion (due to aspergillus species), trichomoniasis, salmonellosis, campylobacteriasis, listeriasis and chalamydiosis this all infectious disease are indicated in Table 1 \& 2 [16,17]. The noninfectious cause includes genetic defect, multiple fetuses, injuries, toxicities and drug induced abortions, hypoxia and acidosis, high material temperature due to pyrexia, severe trauma and heat stress that causes fetal death [18]. Abortion in cattle is a significant cause of reproductive wastage and is of economic importance as a single abortion event in a dairy herd is estimated to cost more and abortions are due to infectious diseases, several of which are zoonotic.

The clinical signs of abortion differs depending on their causative agent but the most common are fetal death and abortion, placentities, necrotic cotyledon and edematous, infertility and its prevention and control depends on the causative agents and the common control and prevention method is control of exposure to the causative agent, regular immunization against disease that cause abortion, proper housing, handling and environmental control regarding sanitation, artificial insemination and balanced nutritional programs is essential [7].

\section{Retained fetal membrane}

Retained fetal membranes (RFM) are a condition in which a cow fails to expel her fetal membrane (after birth) within 12 hours after parturition. Retention of fetal membranes (RFM) for greater than 12 hours after parturition is associated with increased postpartum disease, decreased milk production, reduced reproductive performance, and increased culling rates. The cotyledonary placenta of cows is usually expelled within 3 to 8 hours after parturition and is considered retained if not expelled by 12 hours. The cause of retained placenta is failure of fetal cotyledons to separate from crypts of material carbuncles; the process of separation is normally begins during the last month of pregnancy when villi shrinks after blood flow is interrupted by rupture of the umbilical vessels [11].

The precise reasons for separation failure are unknown but a number of factors have been associated with separation failure. The possible factors involved in precipitation of the problem includes specific infections such as Brucella, Leptospira, Campylobacter, infectious bovine rhinotrachietis (IBR) and others, and nonspecific infections by a wide range of bacteria and viruses that occur during pregnancy or at calving, twine birth, nutritional deficiency and deficiency of selenium, vitamin 
E, vitamin A are associated with an increased prevalence of retained placenta. Retained fetal membranes (RFM) are more common in dairy than in beef breeds [16].

Numerous factors have been associated with an increased incidence of the disease: Dystocia any trauma sustained by the uterus may cause release of chemicals which inhibit protolysis. Progesterone imbalance-elevated progesterone inhibits collagenase activity and slows uterine involution. Stress glucocorticoids, released in stressful conditions, stimulate production of progesterone in placental tissue and may block proteolytic activity.

Prostaglandin-elevated levels in the prepartum cow lead to RFM. Leucocytes (white blood cells) - reduced leukocytic activity is associated with reduced immune response and increased RFM. Vitamin E/Selenium-deficiencies in these important micronutrients have been associated with RFM. Parturition after shorter or longer than normal gestation length is accompanied by an increase in the incidence of retained fetal membrane than likely to have retained fetal membranes in future calving [19].

It is a common disease in dairy cattle and there are often no signs of systemic illness. However, when systemic signs are present they are usually due to toxemia and should be treated with the use of non-steroidal anti-inflammatory drugs or antimicrobials $[20,21]$. Removal of the retained membranes includes abundance of rank smelling dark-brown, red fluid that is combined with small pieces of placenta in the vagina. Physical investigation of the uterus by one's hand will indicate the severity of the fetal membrane involvement and many clinical examinations of the rectum indicate an overlarge uterus that is loose and lacks ridges, the physical process of placenta separation indicated as Figure 1.

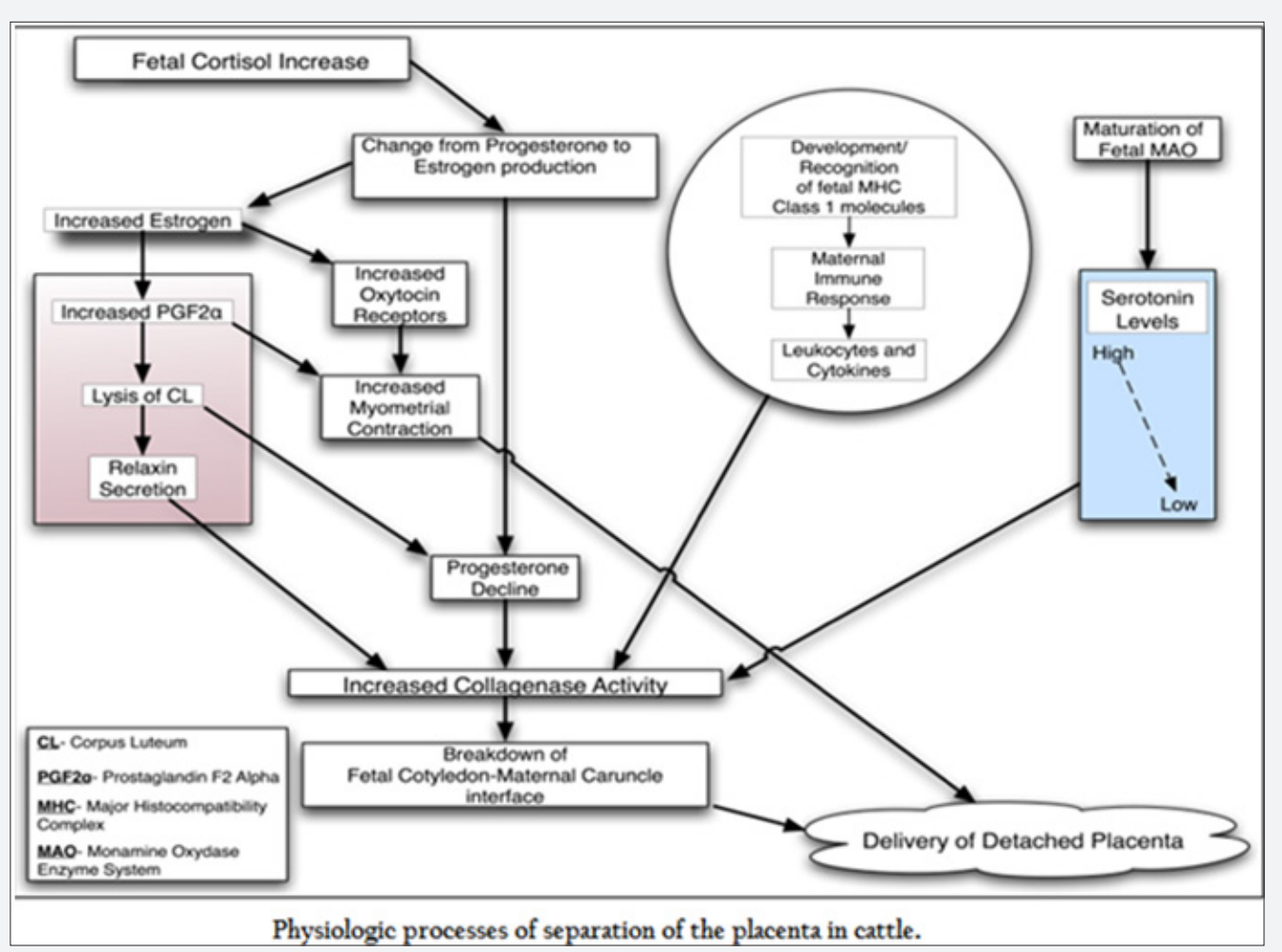

Figure 1 : The physio-mechanism of separation of placenta in dairy cow.

The presence of thick sticky non-foul smelling mucus in the cervix and vagina usually illustrates that the fetal membranes have been released from the uterus [16]. The economic impact of retained placenta is due to a decrease in milk production, an increase an increase in calving interval, and an increase in cull rate and it was also reported that retained placenta decreased conception rate by $14 \%$ when compared with healthy cows [22].

Treatment of retained fetal membranes includes manual removal, use of hormones or antibiotics, collagenase injection, and treatment with hyper osmotic solutions [16]. Manual removal of the retained fetal membranes is risky since it increases the risk of uterine infections versus leaving the animal untreated. If an animal is left untreated it will usually take 2-11 days for the membranes to be released [19].

\section{Endometritis}

Endometritis is an inflammation of the endometrium characterized by reddish brown, white to yellow mucoprollent, vaginal discharge along with thickness of uterine wall detected in trans-rectal palpation [23]. The possible factors involved in the development of endometritis are retentions of fetal membrane, injury to the reproductive tract due to the difficult in calving or excessive force used to assist at calving or injury at the time of breeding or uterine treatment contamination of the reproductive tract at calving, use of uterine boluses (sometimes), 
over conditioning which may predispose cows' to many health problems at the time of parturition or during early lactation including RFM and endometritis [24].

Clinical and subclinical endometritis negatively affect the performance of the world's dairy industry; economic losses are related to delay in the resumption of ovarian activity, increased number of services per conception, decreased milkyield, and costs of treatment of the disease $[25,26]$. Endometritis is considered to be a multifactorial disease with many factors having a direct or indirect, determining or predisposing influence, the summary for risk factor of endometrium in Figure 2 [27].

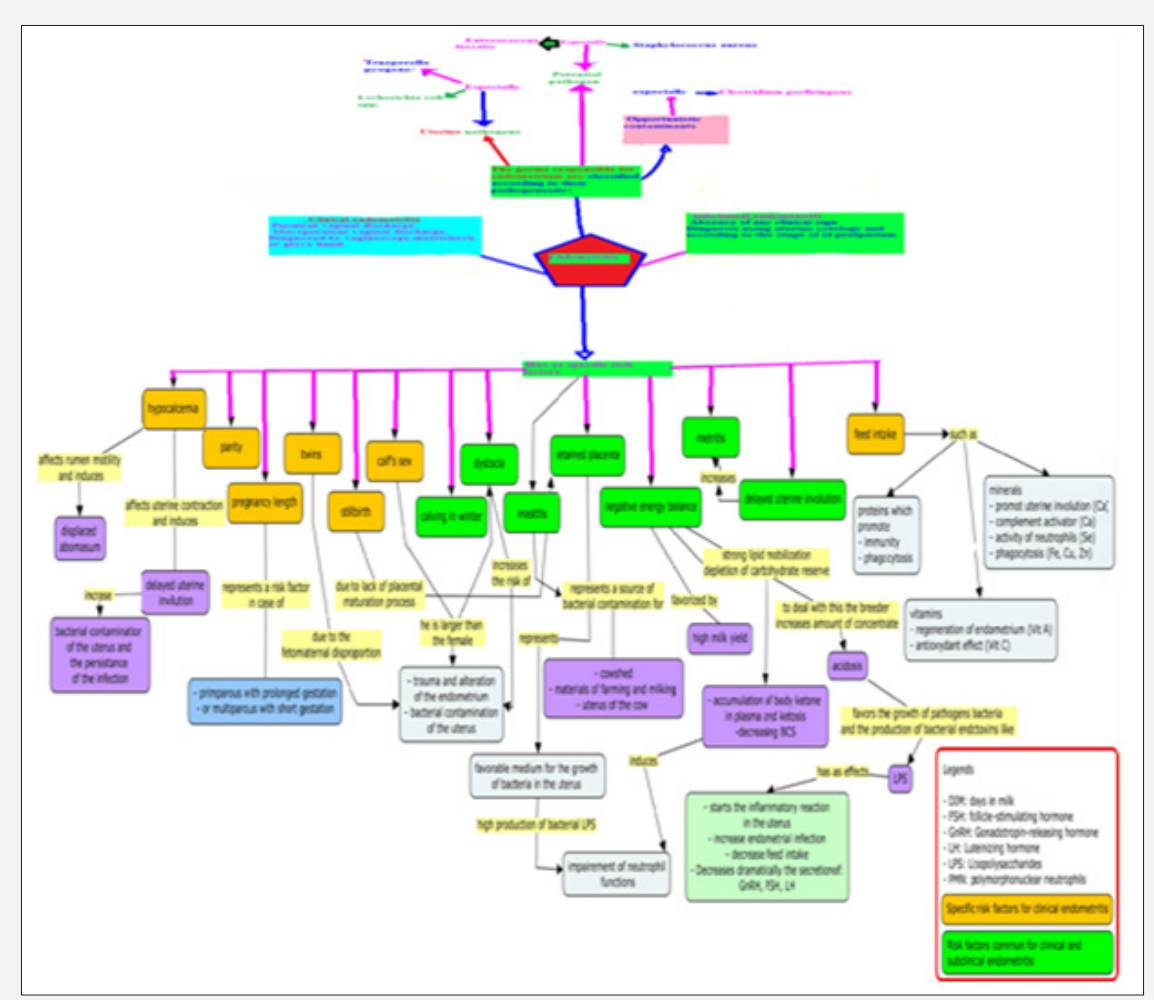

Figure 2 : The major risk factors of clinical and subclinical endometritis [28].

\section{Dystocia}

Dystocia diagnosed as abnormal or difficult birth in which the first or especially the second stage of parturition is prolonged markedly for more than 6 hours and the cow requires assistance $[28,29]$. The problem could be associated with one or more of the following causes; breeding faults, over conditioning of the dam, malformation of the calf or the dam, shortened or lengthened gestation, fetal maternal incompatibility, malposition of the fetus (Figure 3) and other diseases such as milk fever where there is a decrease in calcium which will decrease muscle tone causing the cow to become too weak to push out the calf, or uterine torsion where the cervix is twisted The cause of dystocia is described in Figure 4 [30,31].

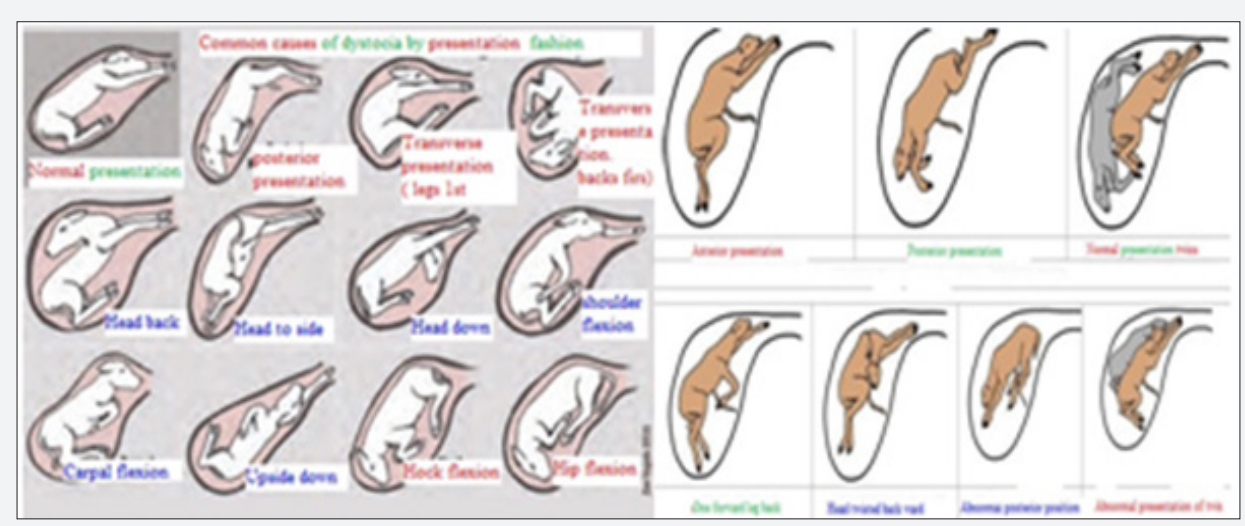

Figure 3 : The picture of abnormal presentation of fetus which cause for dystocia. 


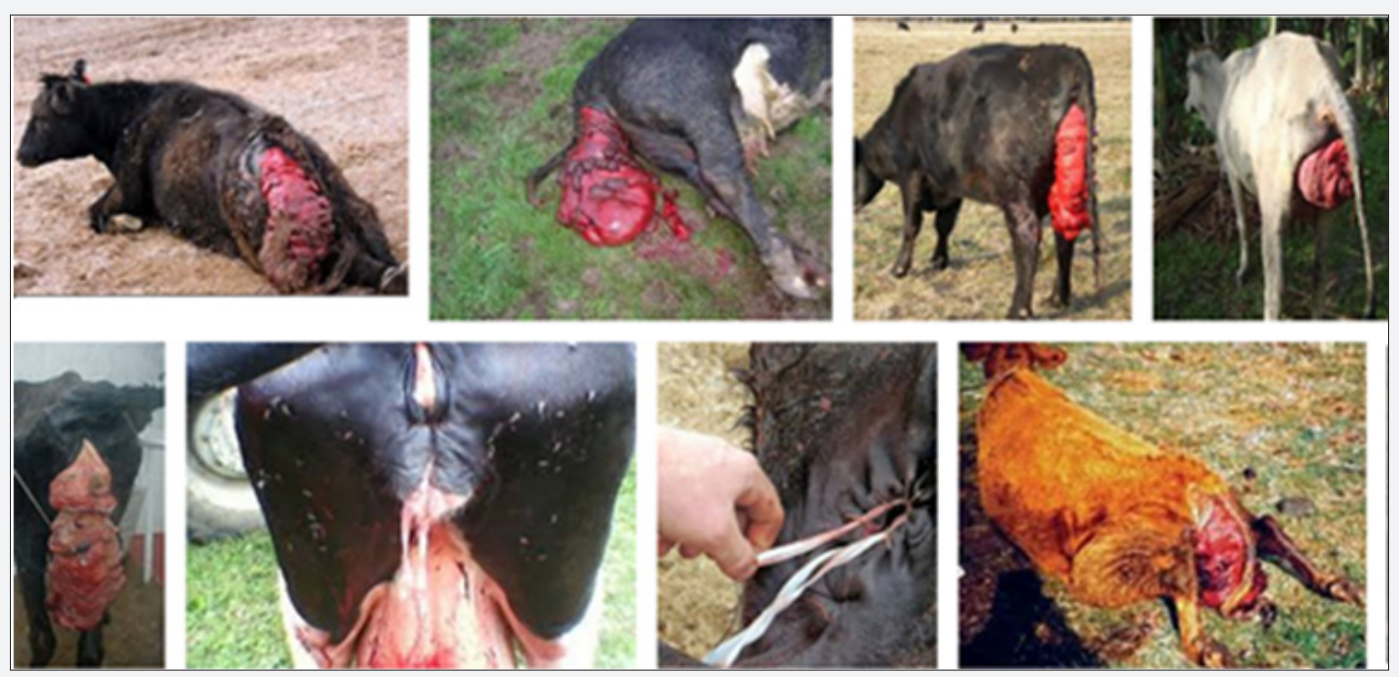

Figure $4:$ The uterine prolapse in dairy cow.

Dystocia causes a huge loss in dairy cattle herds and cannot be predicted but can be reduced by superior management of one's herd: Replacement heifers should be well developed and fed adequately to reach $65 \%$ of their mature weight at breeding parturient cows should be observed no less frequently than every 3 hours, and delivery should be assisted if the first or second stage of labor is prolonged [22].

In order to prevent and treat dystocia one must know history of previous occurrences of difficulty calving for each animal, such as any previous zoonotic diseases which caused an early abortion and current gestation length and the length of time that the animal has been in labor are early predictors of dystocia. If heifer or cow exceeds an adequate amount of time for the first 2 stages of labor, then the dairyman should examine the animal. Since heifers are new to calving, they should be allowed longer time period to give birth [16].

\section{Uterine prolapse}

Uterine prolapse is the coming out of the uterus with or without vagina and cervix through the vulva commonly shortly after parturition and hanged out with the inner surface outer most (Figure 4). It may be caused by increased intra-abdominal pressure associated with increased size of the pregnant uterus, intra-abdominal fat or rumen distention supper imposed up on relaxation and softening of the pelvic girdle, the excessive force of delivery or uterine inertia (the uterus stops contracting) due to metabolic problems (i.e., milk fever). It is difficult to prevent or control the problem but decreasing predisposing factors such as hypocalcaemia, lack of exercise, excessive straining to expel after birth may decrease the incidence [29].

Relaxin is a hormone that remodels connective tissue hereby inducing cervical dilation, pelvic relaxation, and separation of inter pubic ligaments in several mammalian species [32]. In correction or uterine prolapse fist restraining and anesthesing animals is the first option. A caudal epidural block using lignocaine hydrochloride (2\%) was effective in controlling straining and provided satisfactory regional analgesia.

Low doses of xylazine can be added to prolong the duration of analgesia [33]. It also provides sedation for easy restraint of the animal [34]. However, xylazine is contraindicated in pregnant animals, as it may induce abortion [35]. In delayed cases, replacement was more difficult due to the swelling and hardening of the prolapsed mass. Although topical application of osmotic agents, such as sugar or salt, may reduce or prevent edema by squeezing fluids out of the uterus, these agents may also amplify endometrial trauma [36].

Manual massaging during repositioning of the mass after application of an ointment or a lubricant is an effective alternative technique. In the present study, the modified Bühner's technique, using infusion set tubing as suture material, was found to be very satisfactory in preventing recurrence of the prolapse and therefore is recommended as an alternative technique, particularly in developing countries where farmers cannot afford repeated costly treatment of their livestock. The advantages of this modified technique over the standard Buhner's technique include:

a. Sufficient space (between the suture knot and the ventral vulvar commissure) for urination without difficulty,

b. No need to create and suture the incisions above and below the vulva,

c. The suture can be loosened and reapplied by the owner himself, as and when required, or at the time of calving,

d. Quick application with no additional man power and instruments requirement, and v) it does not lead to anatomical disfigurement or physiological defects in the vulvar area [37]. 


\section{Repeat Breeding}

Repeating breeding is one of the major infertility problems of herds. A repeat breeder cow is acow that looks apparently healthy and has regular oestrous cycle [38]. The potential causes of the repeated breeding may be include pathological endometritis,nutritional defiecience, special trace minerals and vitamin $\mathrm{A}$, age of the dam, in approprer heat detection and endocrine dysfunction $[38,39]$.

A cow or a heifer that failed to conceive for three or more consecutive services is named as repeat breeder [23]. Or animals exhibiting regular estrus cycle every 18 to 24 days and normal heat signs but failed to conceive after three or more inseminations are diagnosed as repeated breeders [29]. The possible factors involved are embryonic or early fetal mortality caused by trichomoniasis, letopirosis, and excessive manipulation of reproductive tract by rectal examination and in appropriate time of mating (breeding) i.e. breeding too early or too late in relation to time of copulation, use of low fertile sires, use of semen damaged in storage or handling, poor insemination technique, series imbalances or deficiencies of vitamins (minerals) could result in repeat breeding [23].

The major risk factor for repeat breeding in dairy cattle are like; Abnormalities in Ovulation, causes of fertilization failure, Oviduct obstruction ,Abnormal environment of Oviducts and Uterus, Endocrine Dysfunctione, Genetic or Acquired Defects of Ova, Genetic or Congenital Anomalies of the Genital Tracts, Gonadless Condition and Hypoplasia of the Ovaries and Genetic Defect and Aging of spermatozoa [40]. Repeated breeding have a higher predisposition to be stressed, as evidenced by the increased capacity to produce cortisol from adrenal glands after induced stress. Adrenal progesterone in induced-stress cows reaches suprabasal levels. Thus, stress can be considered as a potential factor in repeated breeding syndrome [41].

It is necessary to diagnose the etiology of reproductive failures in cows having an apparently normal clinical history and then, reduce the economical impact. External inspection can identify congenital or acquired anatomical defects as pneumovagina, vulvar defects, tumors or injuries. The vaginal contents should be inspected to detect urine (if urovagina), pus (if endometritis, vaginitis), blood (post-ovulation or some diseases) or clear and clean mucus (associated with heat). Rectal palpation is a widely used diagnostic method in cattle with high accuracy, easy to be implemented and at low cost in comparison with other sophisticated techniques. At heat, uterus is turgid, erect and coiled. However, it is soft and flaccid during luteal phase and palpation is a bit more difficult; it is a consequence of the progesterone action, released from CL. Palpation helps to diagnose anomalies such as uterine infections.

During anestrus, ovary size ranges from 2 to $3 \mathrm{~cm}$ approximately. Follicles (at different stages of growth) and CLs (hemorrhagic, mature or/and albicans) are developed at the ovaries and its size could suggest some diseases. Ultrasonographic anatomy of foetal sex organs, from genital tubercle (GT) to fully developed organs, has been extensively described in their entire progression. In females, the GT forms the clitoris, the genital swellings completely disappear and the urogenital folds develop to enclose the GT, forming the labia [42].

Sex hormones, neurotransmitters and other substances are involved in the regulation of the sexual cycle in cow. Synthesis, release, actuation or interaction imbalance of these substances could be related to reproductive alterations as repeat estrus and reduced fertility. Progesterone assay is an objective and accurate test to evaluate the ovarian function and to diagnose certain diseases that otherwise could not be correctly determined, such as delayed ovulation, persistent luteal activity, ovarian cysts or suprabasal progesterone levels [43].

The endometrial bacteriological diagnosis is interesting to detect pathogens implicated in infertility. The treatment of repeated breeding in dairy cow can be by hormonal and nonhormonal methods; Nutritional deficiencies have been described as causes of Repeated breeding in dairy cow, therefore the treatment should be given as appropriate of this cause.

Diets containing higher concentration of inorganic iodine from 8-12 days before estrus improve the stimulation of the pituitary gland, reducing at the same time the RBC rate [44]. Herds with problems of repeated estrus were supplemented with copper and magnesium, minimizing fertility problems. Deficiencies of phosphorus and zinc are linked to low levels of progesterone, which could be the cause of failures in fertilization or early embryonic death. Unsaturated fatty acid diets improve the milk yield and embryo development rates when administered at dry and postpartum periods, also being beneficial in repeated breeding in dairy cow. Numerous hormonal treatments have been used to improve results in RBCs. The administration of GnRH around the insemination time aims to accelerate and ensure ovulation in cows, acting directly on the pituitary, stimulating the secretion and release of gonadotrophins, such as LH and FSH, and promoting the preovulatory LH peak, which is essential for follicular dehiscence. Progesterone is essential for implantation and maintenance of pregnancy.

Corpus luteum dysfunction decreases Prostaglandin concentrations and then negatively affects fertility [45]. The luteolytic effect of prostaglandins has been used to treat repeat breeding in cow. In this case, treatment aims to achieve better heat detection and to increase the number of cows in heat.

\section{Anoestrus}

Anoestrus is a state of complete sexual inactivity with no manifestation of oestrus for more than two months [23]. The anestrus condition is associated with the presence of inactive ovaries, and even there is follicular development, none of the growing follicles become mature enough to ovulate [46]. Anestrus can be classified based on ovarian activity; anestrus cow has broadly been classified into ovulatory, anovulatory and inactive. 
The anestrus classified into three classes i.e., anovulation with follicular growth up to emergence; anovulation with follicular growth up to deviation but not ovulatory one; anovulation with follicular growth up to ovulatory size [47].

Further, anestrus divided into fourtypes; Type-I, characterized by emergence of follicular wave and growth of follicle up to pre deviation stage; Type-II, characterized by deviation of follicle and follicle grow up to dominance stage followed by atresia; Type-III, characterized by persistent dominant follicle (persistent of large follicle) i.e. follicle grow up to preovulatory or ovulatory size or more but fails to ovulate or regress (follicular and luteal cyst) and Type-IV, characterized by normal ovulation and formation of corpus luteum but corpus luteum persist beyond the expected time of regression (persistent corpus luteum, PCL) resulting into anestrus. The classification of anestrus is summarized in Figure 5 [48].

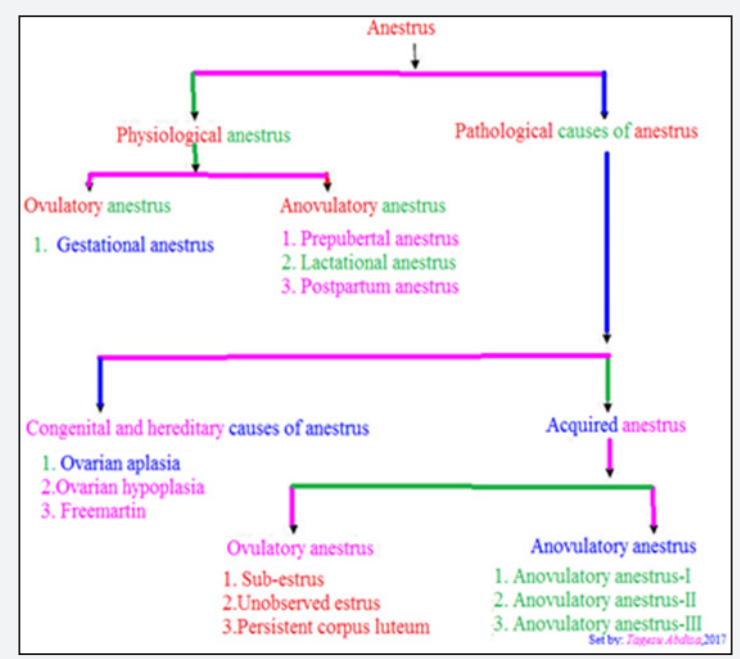

Figure 5 : The picture of abnormal presentation of fetus which cause for dystocia.

The mechanisms controlling postpartum anestrus reside in the hypothalamic-pituitary-ovarian axis, and interactions of this axis with other central nervous systems centers that are involved with lactation/suckling, metabolism, and maternal behavior [49]. Production of large amounts of steroids by the placenta, especially E2 and progesterone, during late pregnancy exerts strong negative feedback effects on the hypothalamus, resulting in a decreased release of GnRH. Increased level of gonadotropin and the release of GnRH from the hypothalamus and gonadotropins from the anterior pituitary increases results in follicular growth and maturation, ovulation, and continued cyclicity [50]. However, the recovery of hypothalamic-pituitary axis and initiation of ovarian activity and ovulation may be delayed, hence increasing the duration of postpartum anestrus in cattle.

Anestrus is a result of many interacting factors; managerial, physiological, pathological and nutritional factors. These factors include age, breed, pre-and postpartum nutrition, body condition at calving, milk yield, suckling, calving season, presence or absence of the bull, delayed uterine involution, dystocia and general health status influence duration of postpartum anestrus [50].

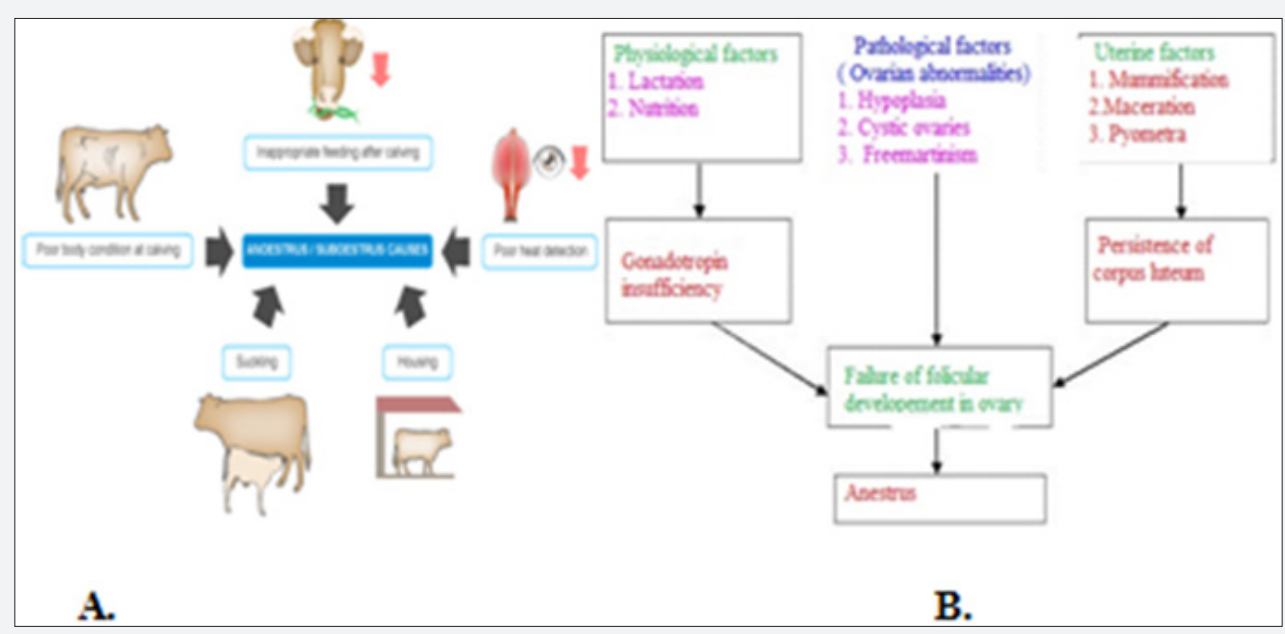

Figure 6 :The main causes of anestrus in dairy cattle. 
Suckling is one of the main factors influencing the length of the postpartum anestrus period [50]. If suckling is continuously practiced during lactation, it blocks ovulation, elongates period of postpartum anestrus, and contributes to a lesser reproductive efficiency and also indicated in Figure 6.

It has been reported that suckling induced suppression of $\mathrm{GnRH} / \mathrm{LH}$ is mediated through a complex neuroendocrine system involving endogenous opioid peptides, i.e., $\beta$-endorphin [50]. The possible factors involved are; in adequate estrous detection, in adequate animal identification and/or in adequate records, lack of ovarian activity caused by anemia, energy deficiency, low hormone levels associated with prolonged feeding, pyometra, quite or silent estrus/ estrus normal ovarian activity with little or no sign of estrus.The treatment which recommend for anestrus is Combinations of progestins, $\mathrm{GnRH}$, and prostaglandin F2 $\alpha$ are quite effective to induce estrus and ovulation, in anestrous suckled cows and peripubertal heifers [51]

The treatment for anestrus is not single case, but its conduct as its cause, therefore treatment can be hormonal and non-hormonal. Non hormonal plant can use for inducing heat. Plants synthesize varieties of phytochemicals such as alkaloids, glycosides, terpenes and tannins (secondary metabolites) as a part of their normal metabolic activity and many of these have therapeutic actions when consumed by animals. Many plants are rich source of vitamins and minerals whereas some have estrogenic property which is useful in restoration of cyclicity in anestrus animals. Almost all the parts of plant such as seeds, berries, roots, leaves, bark and flowers have been used as therapeutic agents either directly (crude drugs) or their active principles, after separation though various chemical process. Many plants such as Murrayakoenigii (curry leaves), Nigella sativa, Abromaaugusta, Saracaasoca, Trigonellafoenum-graecum, Bambusaaruninacea, Carica papaya, Asparagus recemosus, Leptadenia reticulate, Courupitaguianesis, Pergulaciadaemia Semecarpusanacardium cucumber, and jute plants either alone or in combinations have been fed to treat the anestrus animals with variable response on induction of estrus [ 52,53]. Lugol's iodine is an irritating solution and intrauterine infusion of Lugol's solution (0.5 to1.0\%) causes hyperemia (enhanced circulation) of uterine mucosa resulting into degree of iodine absorption from uterus [54].

The mechanism by which ovarian massage induces cyclicity is not clearly understood, however, probable mechanism includes: activation of intrinsic intra-ovarian factors; enhancement of blood circulation to the ovaries and uterus that increases the availability of hormones and growth factors; stimulation of local oxytocin production by the ovaries which consequently influence local blood circulation and luteolysis, if CL is present [55].

Hormonal treatment of anestrus is by administration of estrogen and progesterone. Exogenous administrations of estrogen produce estrus signs in anestrus animals with or without concurrent ovulation. In presence of dominant follicle, estrogen administration results in expression of estrus and ovulation because of its positive feedback effect over pituitary for LH surge. For this reason, it has been used to induce ovulation [56].

Exogenous administration of progesterone mimics the luteal phase of the estrus cycle by exerting negative feedback effect over hypothalamus and pituitary for LH release. Upon withdrawal of progesterone, the normal follicular phase of the cycle is stimulated. However, for such treatment seem to be effective, abrupt decrease in progesterone level is required at the end of treatment. Intravaginal progesterone releasing devices such as PRID (progesterone-releasing intravaginal device), CIDR (controlled internal drug release) and Cue Mate are effective in restoration of cyclicity in anestrus animals $[57,58]$.

The single intramuscular injection of GnRH analogue (10 to $20 \mu \mathrm{g}$ Buserelin) has been used effective in induction of estrus and concurrent ovulation with variable response ( 45.5 to $87.5 \%$ ) within 4-22 days $[59,60]$. Pregnant mare serum gonadotrophin (PMSG) or equine chorionic gonadotrophin (eCG) is strong stimulator of ovarian activity because of its predominant FSH like activity. Therefore, it has been used extensively for superovulation. However, single intramuscular injection in low doses either alone or in combinations with others has been used successfully to treat anestrus cattle $[60,61]$.

Prostaglandin (PGF2 $\alpha$ ) is the treatment of choice for persistent corpus luteum and sub estrus. Natural or synthetic analogue of PGF $2 \alpha$ as a single dose has been used with a reasonable degree of success for management of silent estrus in cattle and buffaloes [62]. Generally, it is well known that reproductive problems result in a considerable economic loss both at a household and national level necessitating effective prevention means to minimize the problem [63].

\section{Mastitis}

Mastitis is the inflammation of the mammary gland characterized by physical and chemical changes in milk and caused by physical injury, chemical agents and by microorganisms, mainly by several types of bacteria, some fungi and mycoplasmas. The most important changes in milk are discolouration, presence of lumps and increase in the number of inflammatory cells, known as somatic cell counts [64]. Mastitis is one of the most diseases of dairy cattle which cause decreasing the economy of the developing country. The economic losses effect of mastitis are mostly due to losses milk production, premature culling or removal from the herd, unsalable or poor quality milk, cost of veterinary care and medicines [65].

At least, 137 infectious causes of bovine mastitis are known to date and in large animals the commonest pathogens are staphylococcus aureus, streptococcus agalactiae, other streptococcus species and Coliform as reported by Livestock improvement [66]. Staphylococcus sp. is the main aetiological agents of clinical and subclinical mastitis in cows while, S. aureus and Escherichia coli are most commonly isolated pathogen from the clinical mastitis, coagulase negative Staphylococci (CNS) are 
the most frequently isolated pathogens from the subclinical cows mastitis [67]. The major bacteria can be split into two categories, those that are cow associated (or contagious), and those which are environmental in origin [67]. The cow-associated bacteria are Staph. Aureus and Strep.Agalactiae while the main environmental bacteria are Strep. Uberis, Strep. Dysgalactiae and coliforms [68]. The most important major pathogens involved in bovine mastitis worldwide are Staphylococcus aureus, Streptococcus uberis, Streptococcus dysgalactiae, Streptococcus agalactiae, Escherichia coli and Klebsiella spp [68].

Mastitis can be tested by somatic cell count, calfornia mastitis test and microbiology processing or strain isolation. Currently, Veterinarians are treating the mastitis disease in bovine animals by applying a wide range of antimicrobials that used in both treatment of clinical and subclinical bovine mastitis, such as benzylpenicillin G (for Streptococci ), cloxacillin (penicillinresistant Staphylococci ), ampicillin ( Gram positive and gram negative, ineffective against penicillin resistant Staphylococcus ), cephalosporin (gram positive and gram negative, ampicillinlike), neomycin (broad spectrum), gentamicin (gram negative), streptomycin and dihydrostreptomycin Chloramphenicol (broad spectrum, especially for Streptoccus and Staphyloccus) [69]. The most important thing is that prevention and control of mastitis disease by the following recommendations: Disinfection of nipples after milking, Treat clinical cases of mastitis in atimely manner, dry all cows with appropriate antimicrobial, eliminate cow with chronic cases, elaborate specific objectives to keep the udder healthy of all dairy cows, maintain an environment that favors the well-being of cows, mainly in relation to their hygienicsanitary health, maintain adequate aspects of biosecurity and periodically monitor the health status of the mammary glands of the cows [69].

\section{Conclusion and Recommendations}

The ultimate goal in dairy farm should be to shorten calving interval of cow, decrease the number of services per conception thereby increasing farm production. But reproductive health disorders such as anestrous, abortion, dystocia, repeat breeding and mastitis, and a RFM affect the reproductive performance of dairy cows, the number of potential replacement needed to maintain a constant dairy cow's size and the longevity of the cow in the herd. Up on closer examination of the reproductive process in dairy cattle, the reproductive diseases was the most varied and the most vulnerable problems that incidentally coincides with the reduction of milk production, prolonged uterine involution, resumption of ovarian activity and conception. Therefore, these reviews stand to write the most common problem of reproductive system and its impact in dairy animals.

As concerning with above conclusion the following recommendation shall be forwarded:

o Giving awareness to farm owners, attendants and improve management such as, proper feeding, accurate heat detection, considering the size of sire and dam while using AI. o Routine and periodical examination of cows during postpartum and prepartum was essential; while most cows acquire reproductive problem during this periods.

o Proper formulation of strategic control measures of reproductive problems, including health education about the disease transmission, to reduce associated reproductive wastage and their risks factors is very important in studied farm.

o The dairy cow should be kept in hygienic condition and rescreening the animals to detect presence of mastitis

\section{Acknowledgement}

I praise my creator almighty God for his love

Secondly I would like to thank Jimma University, JucavmIct center and my family for their support.

\section{References}

1. Lobago F, Bekana M, Gustafsson H, Kindahl H (2006) Reproductive performances of dairy cows in small holder production system in Selalle, Central Ethiopia.Trop. Anim.Health Prod 38: 333-342.

2. Msangi BS, Bryant, Thorne MJ (2005) Some factors affecting variation in milk yield in crossbred dairy cows on smallholder farms in NorthEast Tanzania. Trop Anim Health Prod 6: 403-412.

3. Arthur GH, Noakes DE, Pearson H, Perkinson TJ (1996) Veterinary Reproduction and Obstetrics. Theriogenology $\left(4^{\text {th }}\right.$ edn), Bailliere Tindal Great Britain, UK, pp. 291-301.

4. Lobago F, Bekana M, Gustafsson H, Kindahl H (2006) Reproductive performances of dairy cows in small holder production system in Selalle, Central Ethiopia. Trop Anim Health Prod 38: 333-342.

5. Robert S J (2000 Veterinary Obstetrics and genital diseases. Theriogenology ( $5^{\text {th }}$ edn). Edwards' Brothers, Inc., Michigan, p. 48-104.

6. Erb HW, Martin SW (1980) Interrelationship between production and reproductive disease in holstain cows. J dairy Sci 63: 1911-1917.

7. Lucy MC (2001) Reproductive loss in high producing dairy cattle: where will it end? J Dairy Sci 84: 1277-1293.

8. Badingla L, Thatcher (2009) Inter relationships of milk yield, body weight, and reproductive performance Dairy Sci 68: 1828-1830.

9. Hafez ES (1993) Reproduction in farm animals ( $4^{\text {th }}$ edn). Lea and Febiger, Philadelphia, USA, p. 13-25.

10. Bekana M, Ekman T, Kindhal H (2011) The major reproductive health problems in small holder dairy production in and around Nazareth town, central Ethiopia. J Dairy Sci 71: 2572-2583.

11. Jaster EH (2009) Dairy Cattle Management. DSCI 333 Lecture and Activity Notes. El Corral Publications. Poor Richards Press. Cal Polytechnic State University. San Luis Obispo, California USA.

12. Getachew E, Nibret M (2014) Department of Veterinary Clinical Studies, Faculty of Veterinary Medicine, University of Gondar, Gondar, Ethiopia.

13. Simret H, (2010) Major reproductive disorders of dairy cows in and around mekelle. DVM thesis, college of Veterinary Medicine, Mekelle University, Mekelle, Ethiopia.

14. Adane H, Yisehak T, Niguse T (2014) Assessment of Major Reproductive Disorders of Dairy Cattle in Urban and Per Urban Area of Hosanna, Southern Ethiopia. Animal and Veterinary Sciences. 2(5): 135-141.

15. Hutchinson LJ (2009) Trouble shooting infertility problems in dairy cattle. Pennsylvania State University. 
16. Radostits OM, Blood DC (2001) Veterinary Medicine: A Textbook of the Diseases of Cattle, Sheep, Pigs, Goats, and Horses ( $8^{\text {th }}$ edn $)$ pp. 39-46

17. Richard W (1993) Dairying Tropical Agriculturalist ( $1^{\text {st }}$ edn) Macmillan Press London. p. 43-48.

18. Kennedy (2014) The Early Sixties, and Visitation by the Angel of Death Veterinary Pathology 51(6): 1051-1062.

19. Maas J (2009) Treating and preventing retained placenta in beef cattle. ucd vet views: california cattlemen's magazine.

20. McDougall S (2001) Effect of intrauterine antibiotic treatment on reproductive performance of dairy cows following periparturient disease. New Zealand Veterinary Journal 49(4): 150-158.

21. Merck CO (1998) The Merck Veterinary Manual ( $8^{\text {th }}$ edn) INC, Whitehouse Station, USA, pp. 1017-1026.

22. Young RS, Walter RT (1997) Current Therapy in Large Animal Theriogenology ( $\left.2^{\text {nd }} e d n\right) . p p .339-373$.

23. Takele A, Gizaw Y, Bekana M (2005) Major reproductive health problems in holder dairy production in and around Nazreth town, central Ethiopia. DVM thesis. Faculty of veterinary medicine, Addis Ababa University, Debrezeiet, Ethiopia.

24. Gilbert RO (2016) Management of reproductive disease in dairy cows. Veterinary Clinics: Food Animal Practice 32(2): 387.

25. Cheong SH, Nydam DV, Galvao KN, Crosier BM, Gilbert RO, et al. (2011) Cow-level and herd-level risk factors for subclinical endometritis in lactating Holstein cows. J Dairy Sci 94: 762-770.

26. LeBlanc SJ (2008) Postpartum uterine disease and dairy herd reproductive performance: a review. Vet J 176: 102-114.

27. Prunner I, Pothmann H, Wagener K, Giuliodori M, Huber J, et al. (2014) Dynamics of bacteriologic and cytologic changes in the uterus of postpartum dairy cows. Theriogenology 82: 1316-1322.

28. Adnane M, Kaidi R, Hanzen C, England GC (2017) Risk factors of clinical and subclinical endometritis in cattle: a review. Turkish Journal of Veterinary and Animal Sciences, 41(1): 1-11

29. Tigre W (2004) Major clinical reproductive health problems of dairy cows in and around Holleta. DVM thesis. Faculty of Veterinary Medicine Addis Ababa University, DebreZeit, Ethiopia.

30. Retained fetal membrane in cow.

31. Tyler HD, Ensminger ME (2006) Dairy Cattle Science ( $4^{\text {th }}$ edn). Pearson Prentice Hall. Columbus, Ohio, USA pp. 371-381.

32. Lloyd AL (2011) Effect of relaxin on parturition in ruminants.

33. Noakes ED, Parkinson TJ, England GC (2001) Chapter 5. Prolapse of the vagina and cervix ( $8^{\text {th }}$ edn). In: Arthur's Veterinary Reproduction and Obstetrics. Harcourt (India) Pvt. Ltd., New Delhi, India, pp. 145153

34. Ivany JM, Muir WW (2004) Chapter 6: Farm animal Anesthesia. In: Fubini SL, Ducharme NG (Eds.), Farm Animal Surgery (1 $1^{\text {st }}$ edn), Saunders, St. Louis, pp. 97-112.

35. Fazili MR, Bhattacharyya HK (2008) Pros and cons of using xylazine class of drugs in veterinary practice. IntasPolivet: 20.

36. Miesner MD, Anderson DE (2008) Management of uterine and vaginal prolapse in the bovine. Vet Clin Food Anim 24: 409

37. White A (2007) Uterine prolapse in the cow. UK Vet 12: 1-3.

38. Katagiri S (2011) A new approach to repeat breeding in cows. Treatments targeting the endometrial growth factor-cytokine network. J Vet Med Supp (44): 51-53.

39. Ahmed FO (2009) The efficacy of intra-uterineinfusion of Iodine compounds on the reproductive efficiency of postpartum and repeat breeder dairycows in the Sudan. PhD thesis, University of Khartoum, Sudan.

40. Haimanot BW,Tewodros AM (2016) Risk Factors of Repeat Breeding in Dairy Cattle. Addis Ababa University, College of Veterinary Medicine and Agriculture, Bishoftu, Ethiopia. Advances in Biological Research 10(4): 213-221.

41. Bage R (2002) On repeat breeding in dairy heifers. With special focus on follicular dynamics, ovulations, and oocyte quality. SLU, Doctoral thesis.

42. Quintela LA, Becerra JJ, Pérez-Marín CC, Barrio M, Cainzos J, et al. (2011) Fetal gender determination by first-trimester ultrasound in dairy cows under routine herd management in Northwest Spain. AnimReprod Sci.

43. Waldmann A, Reksen O, Landsverk K, Ropstad E, Kommisrud E (2000) Progesterone at first insemination-effects on non-return and repeat-breeding. $14^{\text {th }}$ International Congress on Animal Reproduction, Stockholm, 15(13): 87.

44. McDonald RJ, McKay GW, Thomson JD (1961) The use of organic iodine in treatment of repeat breeder cows. Proceeding of the $4^{\text {th }}$ International Congress on Animal Reproduction.

45. Kimura M, Nakao T, Moriyoshi M, Kawata K (1987) Luteal phase deficiency as a possible cause of repeat breeding in dairy cows. Br vet J 143: 560-566.

46. Montiel F, Ahuja C (2005) Body condition and suckling as factors influencing the duration of postpartum anestrus in cattle: A review. Anim Reprod Sci 85: 1-26.

47. Wiltbank M, Gumen A, Sartori R (2002) Physiological classification of anovulatory conditions in cattle. Theriogenol 57:21.

48. Peter AT, Vos PLAM, Ambrose DJ (2009) Postpartum anestrus in dairy cattle. Theriogenol. 71: 1333-1342.

49. Short RE, Bellows RA, Staigmiller RB, Berardinelli JG, Custer EE (1990) Physiological mechanisms controlling anestrus and infertility in postpartum beef cattle. J Anim Sci 68: 799-816.

50. Yavas Y, Walton JS (2000) Postpartum acyclicity in suckled beef cows: A review. Theriogenology 54: 25-55.

a. Zadeh AK, Carnahan AC (2011) Understanding Puberty And Postpartum Anestrus. Department of Animal \& Veterinary Sciences, University of Idaho, Moscow.

51. Kumar S, Punniamurthy N (2009) Estrus induction by supplementation of Murraya koenigii in anestrus heifers. Indian J Anim Reprod 30(2): 66-67.

52. Mehrotra S (2002) Studies on ovarian function using certain medicinal plants in rats, goats and cattle. PhD Thesis, I VRI Izatnagar, Bareilly, India.

53. Sarkar AK (2006) Treatment of anestrus cow with diluted logul's iodine and massage on reproductive oragans-uncontrolled case study. Anim Vet Adv 4(8): 734-736.

54. Mwaanga ES, Janowski T, Zdunczyk S, Simukoko H (2010) Ovarian massage: A simple, but useful tool to manage ovarian a cyclicity in dairy cows. Bull Anim Health Prod Afr 58: 294-295.

55. Garcia WM, Lewis PE, Inskeep EK (1988) Ovulation in postpartum beef cows treated with estradiol. J Anim Sci 66.

56. Azawi OI, Ali MD, Oday SA, Salih A, Al-Hadad AS, et al. (2012) Comparative efficacy of different CIDR protocols for the treatment of postpartum anestrous in Iraqi buffaloes. Vet World 5(4): 20-205.

57. Singh V, Malik RK, Singh P, Tuly RK, Verma AK, et al. (2010) Induction of cyclicity in murrah buffaloes-Heifers during summer using different hormonal protocols. Indian J Anim Reprod 31(2): 11-14

58. Markandeya NM, Patil AD (2003) Studies on hormonal therapies for induction of post-partum estrus in buffaloes. Intas Polivet 4(11): 167169. 
59. Prahalad P, Rao KS, Raju KGS (2010) Effect of GnRH, PMSG and Placentrex on reproductive performance of postpartum true anestrus Murrah buffaloes. Indian J Anim Res 44(3): 201-204.

60. Muneer S, Sadasiva RK, Solmon RKG (2009) Efficacy of GnRH-PGF2 $\alpha$, PMSG and PMSG +hCG in postpartum anestrus crossbred cows. Indian J Anim Reprod 30(1): 7-9.

61. Singh M, Sood P, Vasistha NK, Singh C (2001) Study on the use of prostaglandin F2 $\alpha$ in treatment of subo estrus cows. Indian Vet J 78 : 815-816.

62. Noakes ED, Parkinson J T, \& England CG (2009) Veterinary reproduction and obstetrics ( $9^{\text {th }}$ edn). Sounders Elsevier, pp: 319-411.

63. Cruz EJ (2015) Health of the udder. The Importance of Mastitis Control. EntornoGanadero 71: 32-36.

This work is licensed under Creative Commons Attribution 4.0 Licens DOI: 10.19080/JDVS.2018.05.555655
64. Hogeveen H, Huijps K, Lam TJ (2011) Economic aspects of mastitis: new developments. New Zealand Veterinary Journal 59(1): 16-23.

65. Kumar VN, Bharathi MV, Porteen K, Sekar M (2016) Milk Ring Test as Ready Aid to Diagnose Bovine Brucellosis in Lactating Cows of Tamil Nadu, India. J Adv Dairy Res 4: 161.

66. Islam MA, Islam MZ, RahmanMS, Islam MS (2011) prevalence of subclinical mastitis in dairy cows in selected areas of Bangladesh. Bangl J Vet Med 9 (1): 73-78.

67. Livestock improvement (LI) (2001) managing mastitis 3RD ED. A practical guide for New Zealand dairy farmers, New Zealand p. 9-10.

68. Lam TJ, Ruegg PL, McDouglgall (2015) Good veterinary practices on udder health. what to do, what not to do and opportunities. Entorno Ganadero 71: 24-31.

\section{Your next submission with Juniper Publishers will reach you the below assets}

- Quality Editorial service

- Swift Peer Review

- Reprints availability

- E-prints Service

- Manuscript Podcast for convenient understanding

- Global attainment for your research

- Manuscript accessibility in different formats (Pdf, E-pub, Full Text, Audio)

- Unceasing customer service

Track the below URL for one-step submission https://juniperpublishers.com/online-submission.php 